温废に低り相当影彎され $100^{\circ} \mathrm{C}$ が最名甚だ しく, 最低值が $250^{\circ} \mathrm{C}$ 附近に先じ，こ饥は

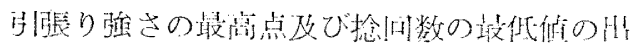
発点と一玫している。そして $300^{\circ} \mathrm{C}$ 以トに 妇なるとセットリング量は俆び急增し引張り 强さは娍少して捻回数は多少上昇子る。

(3) 加熱時間は 2〜60分の間で影響が見られ ない。然し乍ら試験線以普通の回非り強さ $205 \mathrm{~kg} / \mathrm{mm}^{2}$ を遥加超える值 $225 \mathrm{~kg} / \mathrm{mm}^{2}$ 学有して居り，双この状態では加熱㭙開に影 響されにくいと音う点に注意しなけ札ばなり ない。

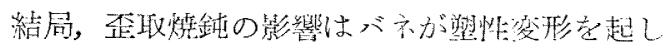

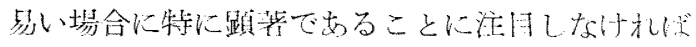

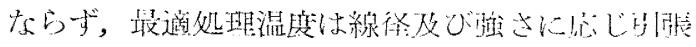

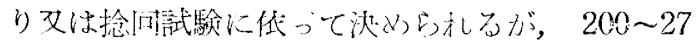

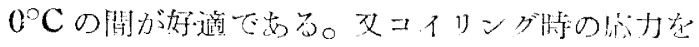

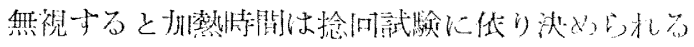

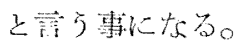

\section{(b) 恒温焼入}

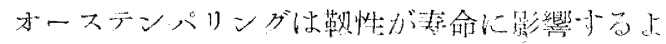

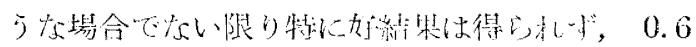
$\% \mathrm{C}, 1.0 \% \mathrm{Mn}, 1.0 \% \mathrm{Si}, 0.6 \% \mathrm{Cr}$ ৩片バホに 就いて S-N 曲線它畞いた处，ナーステンバーに

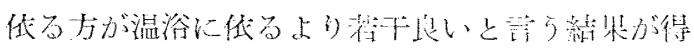

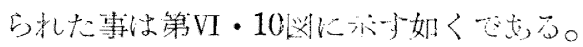

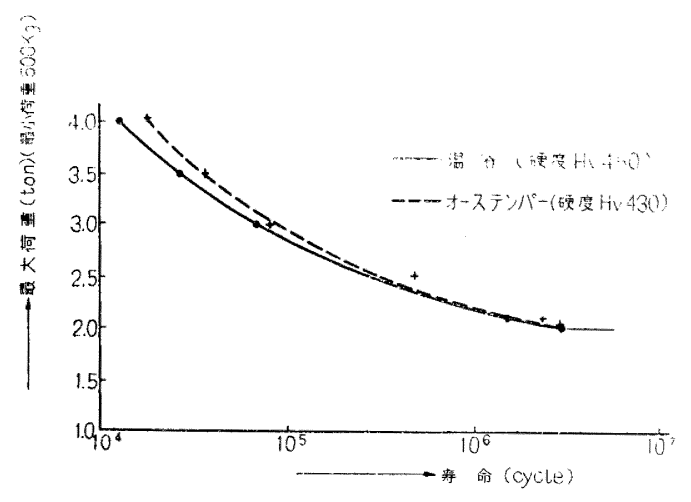

第 VI・10 図 オーステンバーした当のと然らざる ๒のしの害命の比較

\section{(c) 焼 入 剂}

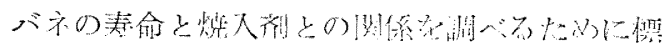

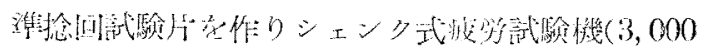

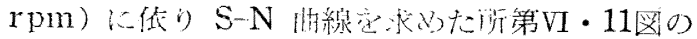
結果孛得大。

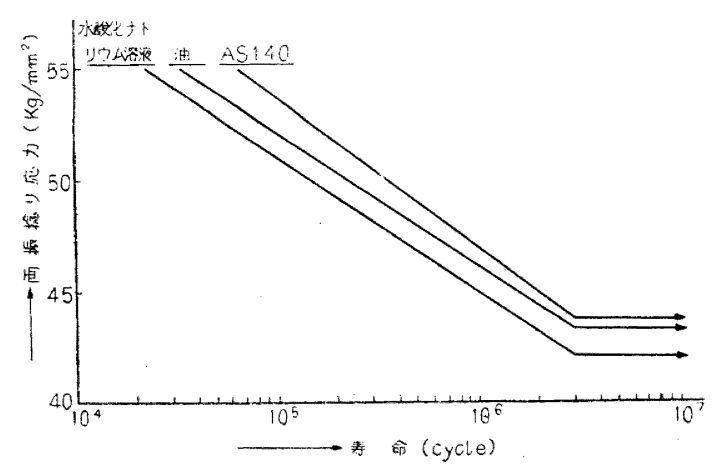

第 VI・11図 バネ材料の寿命に及ぼす焼入剤の影響

但 1.試料は $1.7 \% \mathrm{Si}$ のバネ材で，烧海後 Durferrit 告浴慒 GS $560+10 \% \mathrm{C}_{3}$ て $860^{\circ} \mathrm{C}$ に $5 \mathrm{~min}$

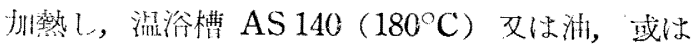
$10 \%$ 水䶼化ナトリウム浴液 $\left(60^{\circ} \mathrm{C}\right)$ に烧入後, Hv $470 \pm 10$ に愤矦したものでせる。即七第VI・

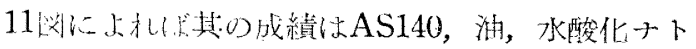

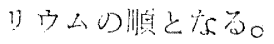

\section{(d) 其 $\odot$ 他}

Walz 以以f:日他资能焼入の一般的説明, 温浴

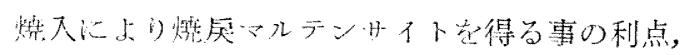
St. C. 45.61 銅穵朋いた塌合高硬度に焼入したも

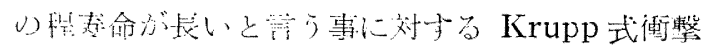

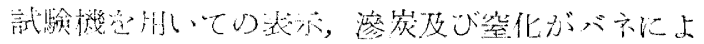

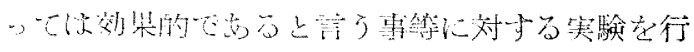
$\because 6230$

\section{5. 冷間加工の効果}

\section{(a) Surface rolling とショットピーニング}

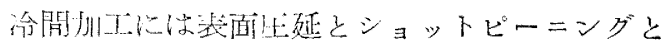
があり，バ亦恻料効して可成の效果がある。裴 闻日:延にしてもショットピーニングにして子效果

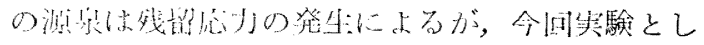

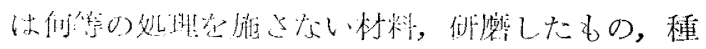
※の条件を゙ョョッドーシングしたもの，ショッ トヒーニング後程取在したすの，サンドブラスチ

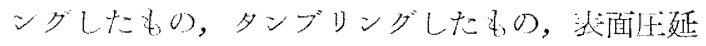

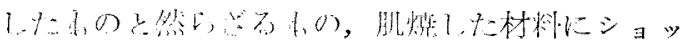

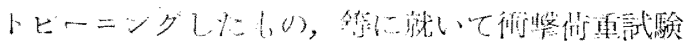


正弦型荷重試験, Krupp 式衝撃試験，等を行。

果の代表例を寺したもので安っ。

た。第VI・12〜VI・14図及び第VI・8表はその結

第 VI・8 表＼cjkstart硬引線バネに対するピーニング効果

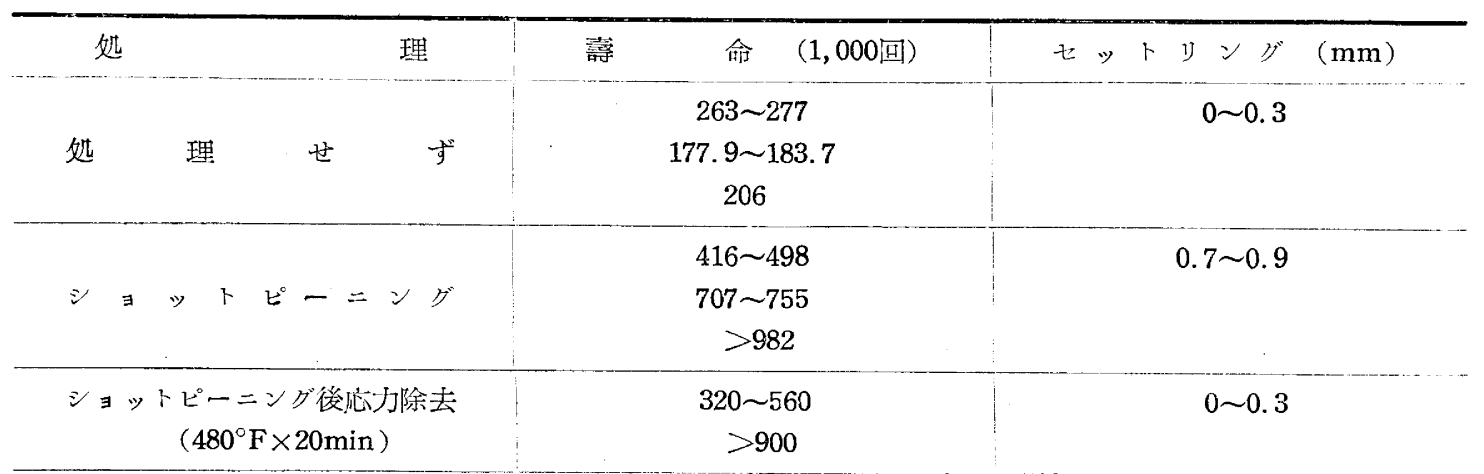

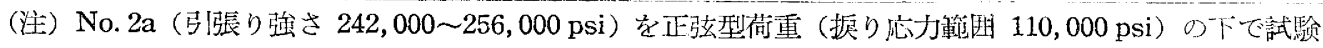

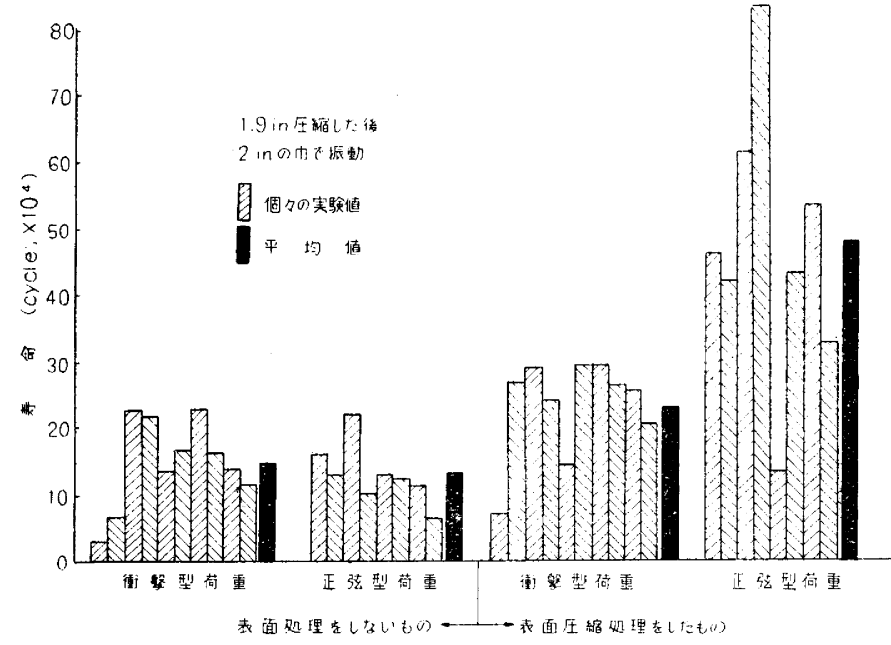

第 VI・12 図 矩型断面を有する卷バネの寿命と表面圧縮處理

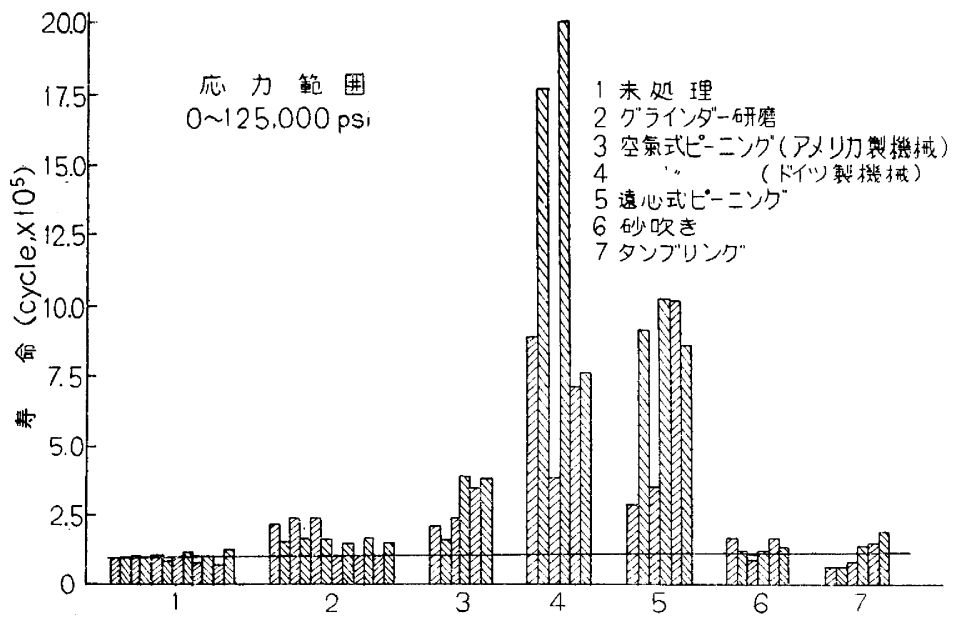

第 VI・13 図種々の冷間表面處理と寿命 


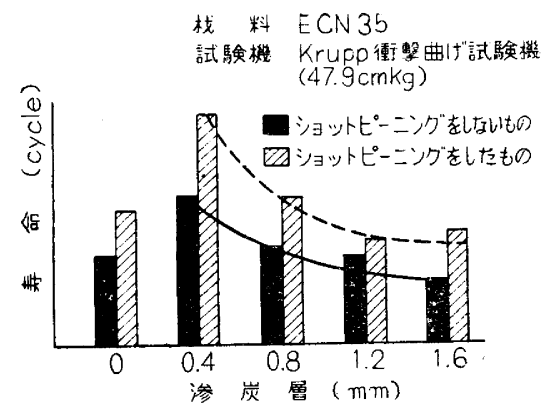

第 VI・14 図滲宸材の寿命とピーニング處理

(b) Surface compression process

Roehrs はピーニングに於ける不安定さを避け 製造方法が簡単で球縮加工の效果を充分举げるこ とを目的として，バ亦を鋼球と研磨剂を満した容
器に入れ，庄力を加えてボールに依る凹痕を付け て冷閉加工を行う方法を案出した。そしてこの方 法は板，枱の如く簡単なるのには效果があったが No. 2C のバネに就いては寿命はかえって減少す る結果となった。

\section{（c）ショットピーニングを施したバネの防蝕}

種々の防蝕処理を施したNo. 5 の皿バ亦を吸收 エネルギー $15 \mathrm{mkg}$ の衝撃荷重で試験した結果は 第VI・9些に示す如く，硬質クロム鍍金孛施した るのが特に覀かった他は鈸金を施さないるのと大 洯のない事が分った。そしてこの場合硬質クロム 鋌金の性質が特に劣った理由としてはバネが歪ん だ䁃に浅面に微細な疵が出来，之が直接破壊の原 因となるものと考えられる。

第 VI・9 表 ショットピーニングを施した皿バネの防蝕處理と寿命

\begin{tabular}{|c|c|c|c|c|c|c|c|}
\hline 琶 & & 溫度 $\left({ }^{\circ} \mathrm{C}\right)$ & $\begin{array}{c}\text { 処理時丽 } \\
\text { (min) }\end{array}$ & 鲟 & 命 & $(1,000$ 回 $)$ & 平均値 $(1,000$ 回） \\
\hline わ & ず & $\ldots$ & - & 31.3 & 29.3 & 28 & 29.5 \\
\hline 錆 & 染 & 140 & 10 & 25 & 25 & 33 & 27.6 \\
\hline 灾力除 & 去 & 140 & 10 & 29 & 24 & 24.5 & 25.8 \\
\hline 技ンダシイ & & 100 & 5 & 36 & 29.5 & 25 & 30.1 \\
\hline 鍍 & & - & - & 30 & 28 & 25.3 & 27.8 \\
\hline 硬質り口ム鍍 & 金 & - & 一 & 17.5 & 16.55 & 17 & 17 \\
\hline
\end{tabular}

\section{6. 腐蝕の影響}

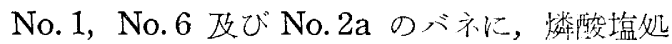
理後ラッカー仕上げ，亜鉛鍍金，種々の厚さの硬 質クロム鍍金，inchromate 処理，等を施したも の, 或は之等の処理を施さないもの等に就いて筷

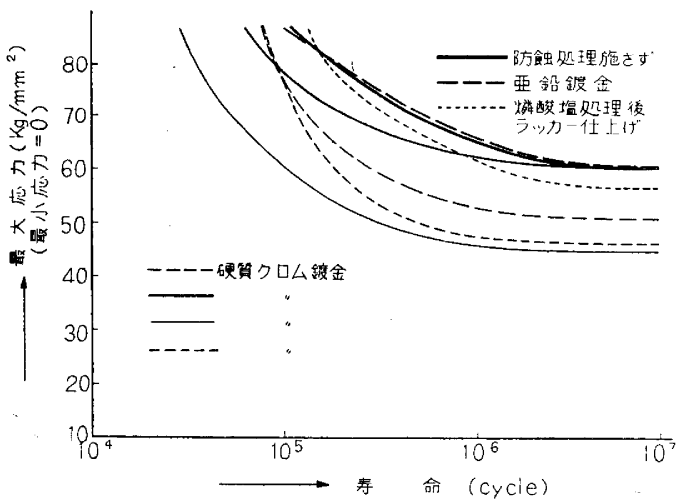

第 VI・15 図防蝕處理直後に於ける寿命と處理方法
蝕の進行前後に於ける衝揧型荷重試験, 疲労試験 等を行った結果は第VI・15〜VI・16住及び第VI・ 10〜 VI・11丰の如くであり，又硬線の引張り強 さに及ぼす簿蝕の影響等は第VI・12表の如くであ る。

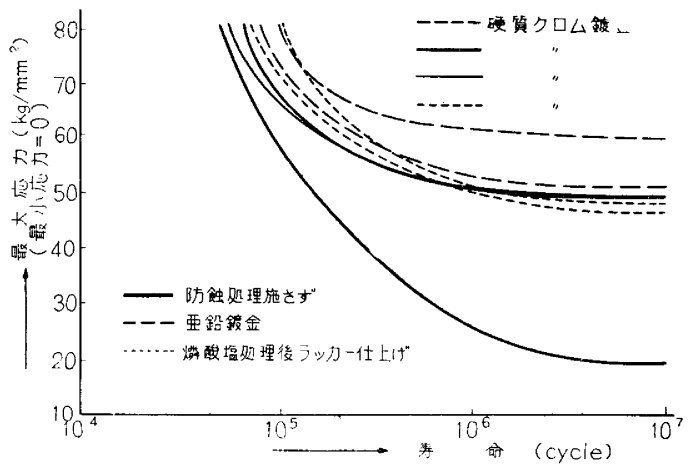

第 IV・16 図防蝕處理より90日後に於ける 寿命と處理方法 
第 $\mathrm{VT} \cdot 10$ 表 防触處理と衝慗荷重試験

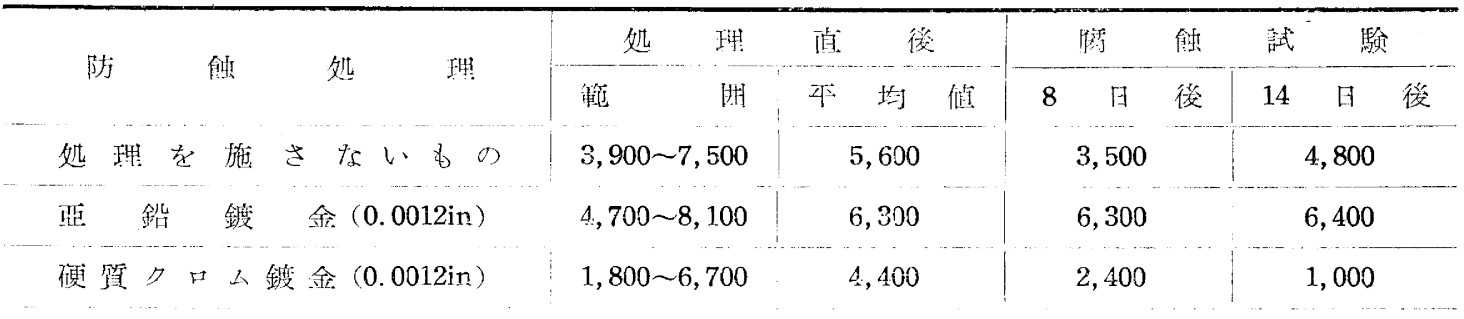

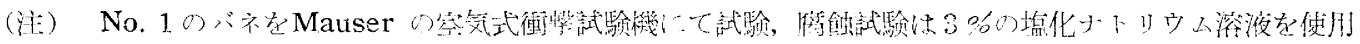

第 VI・11表＼cjkstart燐酸塩處理を施した皿バネの衝擊荷重試験

\begin{tabular}{|c|c|c|c|c|c|c|c|c|}
\hline 製 & 造 & 者 & 处理を施さないるの & 燐 & 酸 & 塩 & 処 & 理 \\
\hline & 1 & & $\begin{array}{c}8,000 \sim 10,500 \sim 12,000 \\
12,000 \sim 8,900\end{array}$ & \multicolumn{5}{|c|}{$\begin{array}{c}15,000 \sim 13,500 \sim 14,200 \\
11,100 \sim 11,900\end{array}$} \\
\hline & 2 & & $\begin{array}{c}13,400 \sim 17,500 \sim 12,200 \\
14,500 \sim 15,400\end{array}$ & \multicolumn{5}{|c|}{$\begin{array}{c}34,000 \sim 32,000 \sim 28,000 \\
27,500 \sim 24,000\end{array}$} \\
\hline
\end{tabular}

（注）バネはNo.6学使朋し，エネルギーの吸收 $2 \mathrm{mkg}$ の条件で陚験

第 VI・12 表 引張り强さに及ぼす霍鰠及び線径の影挷

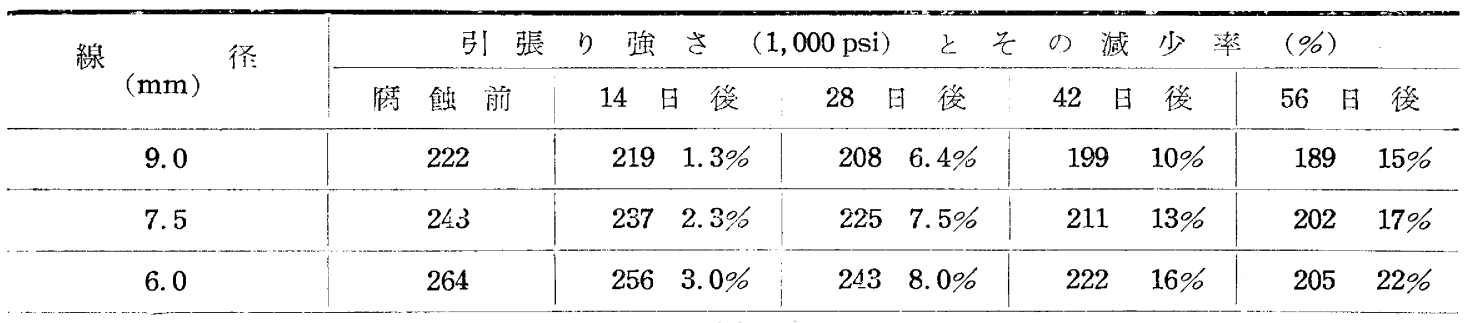

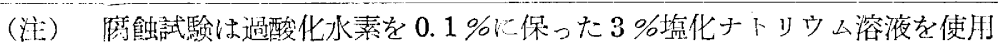

即ちバネは簿創すると共に疲労限が低下する事 は勿䜊・であるが，防蝕処理を施すと疲労限は確保 され燐陵塩，亚鉛，クロム鍍金等の間には大差が

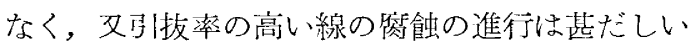
から必然的に引張り強さの低下も著しくなる。

この外 Walz は底力下に於壮試片の簿蝕と
して底力下では笍蝕が速く又 C 量の多いものに之 が著しいこと，応力が弾性限を超える時もこの倾 向が著しいこと及び繰返応力下でも同様の事が豈 える事等を述べた後水素栬性に㠇いて子触れてい るが之は一般諭の域を出ていない。

\section{（3） S A E バネ委員会の批判}

\section{1. 衝擊試驗について}

このエヤヘンマー型試験機は銃砲等のバネに生 ずる状態と同じょうな条件下で試験が出来ると言
万特色があるが，案外ばらつきが多く成績が睘い、 のは，引抜の悪影響のみではなく，不明の要素が 多い点に起因しているのではないかと思う。 而し実際の銃砲等のバ亦に於いて不測の結果が 


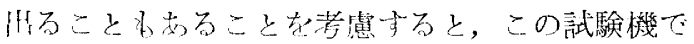

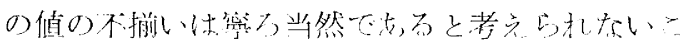

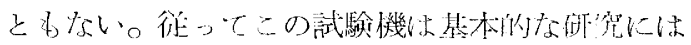
適さないが，特殊目的のためには充分役割な果し 得ると言えよう。

\section{Settling について}

セットリングの寒験は大部分值径 0.122 in の 線に就いて行っているが，アメリカでも 0.122 in 以下の場命はプレテンパー線よりピアノ線を使用 することを潅めている。これより大きい線径の場 合は寿命を遈ばすためにピアノ線よりはプレテン パー線又はコイリング後に熱処理したバネを，又 炭素鍓よりは合金銅を選ぶのが㧹通である。

$\mathrm{Walz}$ は普通の俯力計算の場合, コイルの変位 は総て等しく、コイルには等しい力がかつると若 えたが，変位速度の大なる場合現象は波状に伝播 与る。そしてこれが極めて速い時は一つのコイル が俳のコスルに衝咨し，これが次に変位を起すこ とは理解に難くない。この衝突した瞬間のコスル の平均応力は静的密着時の応力に等しいが，この 際まだ伝播を受故ない側の線内応力は比輘的小さ いと考えられるから，コイルの反対の端部の壳力 は静的密着庄力を超えるものと思われる。而して 更にコイル同志の衝突速度が大き過ぎる時はセッ トリングは激しいものとなる。

Walz は撚線バネの性能は線を据ること自体或 は張り強さの高い紐い線の利脯と言うことから くるのではなく，制御作用にあるのだとしている が，この点アメりカ側の研究と全く一致してい る。

アメリカでの研究は撚線バネの性能の原因を撚 線内の素線の摩擦力に求めて扣り, 撚線バネが型 通のるのより変形し最いためにェネルギーを吸收 ナると言う点をWalz が重視するのは行き過ぎ であると考えている。

Walz は撚線内の素線間摩擦を一是と見ている ようであるが，笑際は速度と共に大きくなるもの である。この現象は過渡波の理䜊から斥顶明がつ く等であるのに、 Walz が之に気村かなかったの は不思議である。

Walz は撚線の lay の長さと共に奉命が延びる
と述ベているが，アメリカでの研究では $11 \mathrm{~d}$

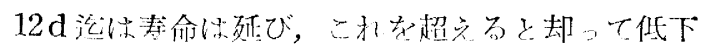
年ると言方結果が出ている。

\section{3. 熱処理の影響について}

Walzは種乃の熱処理とこれによる卷バネの寿 命との関係に就いて可成よく纆めている。これに よるとドイッでは，アメリカで普通に使われてい るオイルテンパー線よりは冷間问拔線の方が一般 化しているょうであるが, 寸法の点, 物理的性質 の点等は SAE War Engineering Board の

“Manual on Helical Spring for Ordnance” に示されたものほど高級ではない様である。

Walz はバネ鋓に完全焼入した時, 一次マルテ ンサイトが生ずると述べているが，この組織を得 るにはバネ鋼を焼入剤の中に冷くなるまで放置し なければならず,このような操作はアメリカでは 採用されていないことに注意しなければならな い。アメリカでは歪や微細な割れを防ぐためバネ は未だ熱い内に引上げるのであって，この結果生 ずるのは焼危マルテンサイトである。

オーステンパリングの利点に就いてはアメリカ 側の経験とは一琼しないことがある。オーステン パーしたバネのセットリングは硬度から推定され る值より遥かに大きいのである。然し低い応力の バネに対してオーステンパーしたもの〉效果が大 きいと言う点ではアメリカの意見と一致してい る。

\section{4. 冷間加工効果について}

Walz は矩形断面の線で造ったバネには表面の ローリング処理を行うことが出来ると簡単に述べ この效果を示すために阷命試験の結果を示してい るが、このローリングの操作を詳細に記述してい ないのは残念である。

ショットピーニングに閔吉る限りこの報告はア メリカの研究者の行ったもの程顕著点成績を示し てはいないが良好である。

ショットピーニング機に就いてドイッの機械は アメリカのより優秀であるかのような印象を受け るが，アメりカではどんな型のバネに対しても Walz が V.\& S. “sand sparker” と呼んでいる 


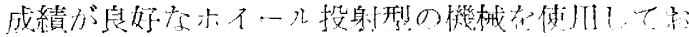

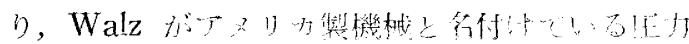

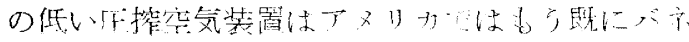

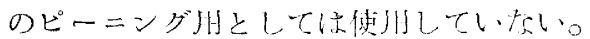

ホイール型 “ sand sparker”機によろショッ

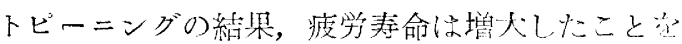
報告しているが，こ扎は大体期待された值萑示し ている。

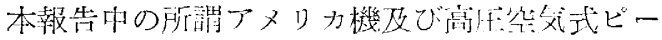
ニン・グ機を使用した時の結果がばらばらて成續が

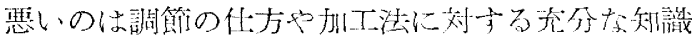

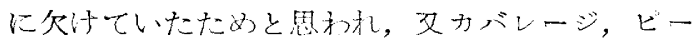

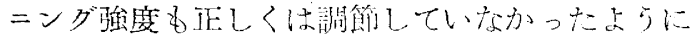

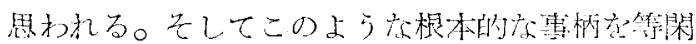
にしていたことが Mauser-Werke ていフメり カのように急速にビーニング加てが発器しなか。 たことの原因と思执る。

\section{5. 腐蝕の影響について}

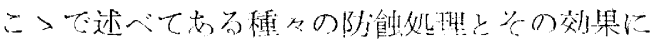

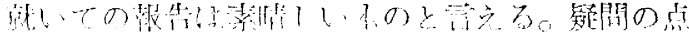

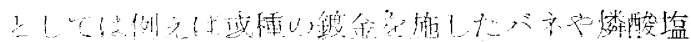

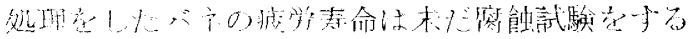

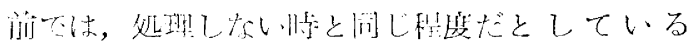
が，テメリカ倒の見儌としては，試験の数を堌や したら别の結果が出せたでからと奴ている。

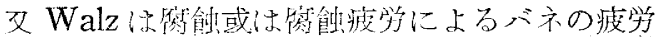
春命の低下老重視し過ざてい。バネ心静的条件

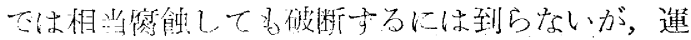

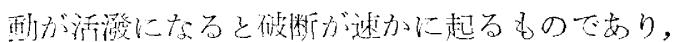

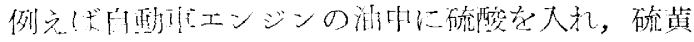
0.1\%の条作下て試験子るとバルブスプリングは

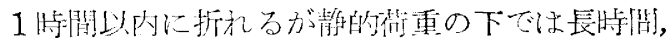

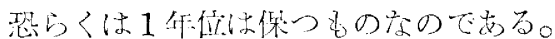

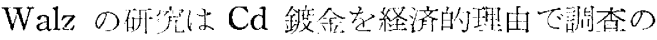
詨等から除外しているが，フメリカでは Cd 鉏全。

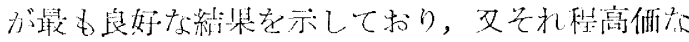

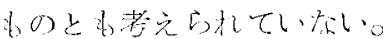

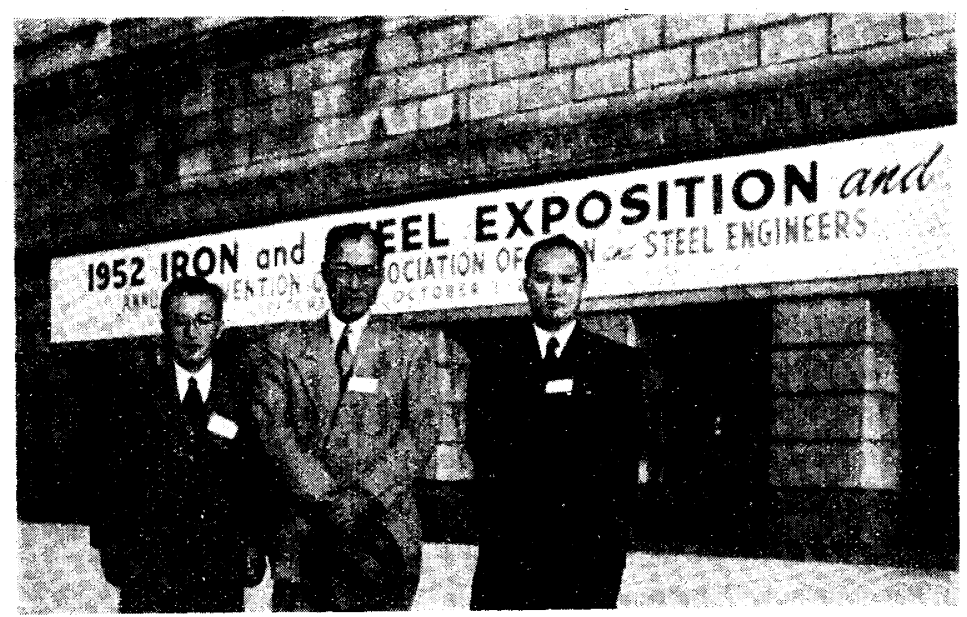

1952 Iron and Steel Exposition (Cleveland 南公全堂にて) 


\section{（4）引用文献}

K. Walz はこの様な報告をまとめるに当り多 数の文献を引用しているが，同時に亦 SAE バネ 委員会も多数の文献を楯に前記の様な批判を㞦え て居り，意見の一致している所は鬼も角，意見の
一致していない所は我々としても特に興味深いも のがある。低って次に参考の為両者の引用した文 献を列記して置こう。

\section{K. Walz の引用文献}

1. Akademische Verlagsgesellschaft Becker und Erler K. G. - Leipzig, 1943.

2. Albrecht, C.: The Warm Bath Hardening Method (Die Warmbadhaerturg).- Haertereitechnische Mitteilungen, vol. 1, 1942.

3. Bardenheuer, P. and Ploum, H.: Mitteilungen der KWI fuer Eisenforschung 16/1984.

4. Becker, G., Daeves, K., Steinberg, F : Surface Improvement by Chrome Diffusion (Oberflaechenveredelung durch Chromdiffusion). Metallwirtschaft, No. 9/1941.

5. Becker, G., Daeves, K., Steinberg, F.: Surface Treatment of Steel by Chrome Diffusion (Oberflaecherbehandlung von Stahl durch Chromdiffusion). Stahl und Eisen, vol. 61 (1941), No. 12.

6. Beilhack, M.: The Endurance Impact Bending Test (Der Dauerschlagbiegeversuch). Forschung auf dem Gebiet des Ingenieur-Wesens, edition B, vol. 3/32.

7. Buschmann, E.: The bending-tensile test method (Das Biegezugverfahren). Zeitschrift fuer Metallkunde, No. 12, December 1934.

8. Cornelius, H. and Bollenrath, F.: Torsional Endurarce Limit under Reversed Loading of Steel Shafts with high Tensile Strength (Verdrehwechselfestigkeit von Stahlwellen mit hoher Zugfestigkeit). Z. VDI. vol. 86, 7/8, 1942.

9. Davenport, E. S.: Steelvol 100, March 15, 1937.

10. Davenport, E. S., and Bain, E. C. : Transformation of Austenite at Constant Subcritical Temperatures. Iron and Steel, No. 56, 1930.

11. D. R. P. (German patent) No. 715, 515.

12. Eggert, J.: Textbook of Physical Chemistry (Lehrbuch der physikalischen Chemie). Publisher S. Hirzel, Leipzig, 1929.

13. Endo, H.: Science Reports of the Tohoku Imperial University $17 / 1928$, p. 1265.

14. Evans, U. R.: Corrosion, Passivity and Surface Protection of Metals (Korrosion, Passivitaet und Oberflaechenschutz von Metallen). Publisher, Springer, 1939, p. 491.

15. Foeppl, O.: Mitteilungen des Woehler - Instituts, No. 39, 1943, p. 34.

16. Foeppl, O.: The Surface Compression Process as a Means of Increasing the Endurance Limit of Springs used in Automobile Construction (Das Oberflaechendruecken als Mittel zur Steigerung der Dauerhaltbarkeit der im Kraftfahrzeugbau verwendeten Feder). ATZ No. 12, June 25, 1942.

17. Foeppl, O., Becker, E., and Heydekampf, G. v. : The Endurance Testing of Materials (Die Dauerpruefung der Werkstoffe). Berlin 1929. 
18. Fry, A., Kessner, A., Oettel, R. : The Significarce of the Elastic Limit for the Endurance Limit under Reversed Loading of Steels of Higher Strength (Die Bedeutung der Streckgrenze fuer die Wechselfestigkeit bei Staehlen hoeherer Festigkeit). Archiv fuer das Eisenhuettenwesen, $1940 / 41$.

19. Handbook of Material Testing (Handbuch der Werkstoffpruefung), vol. $1 \& 2$.

20. Hanemann, H. : Some Things which occur in Steel during its Hardening (Ueber einige Vorgaenge im Stahl bei seiner Haertung). - Haertereitechnische Mitteilungen, vol. 1, 1942.

21. Herold, W. : The Strength of Metallic Materials Under Cyclic Loading (Die Wechselfestigkeit metallischer Werkstoffe). Wien 1934.

22. Hotten rott, E. : The Corrosion Fatigue Strength of Steels and its Improvement by Surface Compression (Die Korrosionsschwingfestigkeit von Staehlen und ihre Erhoehung durch Oberflaechendruecken). Mitteilugen des Woehler-Instituts, No. 10, 1932.

23. Houdremont, E. : Hardbook of the Science of Special Steels (Handbuch der Sonderstahlkunde). Publisher Julius Springer, Berlin, 1943.

24. Kaendler, H. and Schulz, E. H. : A New Way to Reduce the Danger of Fatigue Failure (Ein neuer Weg zur Verminderung der Dauerbruchgefahr). Werkstoffausschuss VDEh, Report No. 48, 1924.

25. Koerber, Fr. and Hempel, M. : Dependency of the endurance limit of steel under reversed loading upon the frequency of the test cycle (Abhaengigkeit der Wechselfestigkeit des Stahles von der Lastwechselfrequenz). Mitteilungen KWI-Eisenforschung, Duesseldorf, vol. 18, part 1, 1936.

26. Kroenig, W. U. and Boulitschewa, A. J. : Corrosion and Metal Protection (Korrosion und Metallschutz), No. 12, 1936.

27. Krouse, G. N. : A high-speed fatigue testing machine and some tests of speed effect on endurance limit. Proc. A.S.T. M., vol. 34, 1934, p. 156.

28. Legge: The Industrial Application of Austempering. Metals and Alloys, Aug. 18, 1939.

29. Macchia, O. : The Phosphate Protection (Der Phosphatschutz). Publisher Chemie, Berlin 1940.

30. Machu: Metallic Coatings (Metallische Ueberzuege). Leipzig, 1943.

31. Maier, Karl : Investigation of Driving Spring Vibrations (Untersuchung von Schliessfederschwingungen). Mauseir research reports No. 589 and 754 .

32. Mailaender, R. : Stahl und Eisen, 1928, p. 110.

33. Mauser test report No. 1000: Investigation to establish acceptance tests for music wires of highly stressed weapon springs (Versuche zur Festlegung von Abnahmepruefungen fuer Klaviersaitendraehte hochbeanspruchter Waffenfedern).

34. Mohr, E. : Z. VDI, 1923, p. 337.

35. Mohr, E. : Connection between bending-tensile test and reversed bending endurance limit (Ueber den Zusammen hang zwischen. Biegezugfestigkeit und Biegewechselfestigkeit). Z. fuer Metallkunde, No. 2, February 1938.

36. Mohr, E. : Determination of a value similar to the endurance limit by means of bendingtensile test (Ueber die Bestimmung einer der Schwingurgsfestigkeit nahestehenden Kennziffer mittels Biegezugversuch). Zeitschrift fuer Metallkunde, No. 1, January 1938.

37. Oschatz, H. : Test Machines to Establish the Endurance Limit (Pruefmaschinen zur Ermittlur.g der Dauerfestigkeit). Z. VDI, vol. 80, 1936, pp. 1433-1439.

38. Peter, W. : Influence of Columbium upon the endurance limit of steel (Die Einwirkung des 
Niobs auf die Dauerfestigkeit von Stahl). Archiv fuer das Eisenhuettenwesen, vol, 15, No. 8, 1942.

39. Plank, M. : Reflections on Dynamic Tensile Stresses (Betrachtungen ueber dynamische Zugbeanspruchung). Forsch. - Arb. - Ing., 1913, No. 133.

40. Pomp, A. : The Steel Wire (Der Stahldraht). Publisher Stahleisen, 1941.

41. Progress in Phosphating (Fortschritte auf dem Gebiet der Phosphatierung). First supplementary volume to O. Macchia: The Phosphate Protection. Publisher Chemie, Berlin 1942.

42. Puengel, W. : The Influence of the Treatment subsequent to Drawing upon the Qualities of Steel Wires. (Der Einfluss der Nachbehandlung auf die Eigenschaften von Stahldraht). Stahl und Eisen, No. 41, Vol. 62, 1942.

43. Puengel, W. and Wagenknecht, W. : Influence of annealing the rolled wire, of patenting temperature and of surface decarburization upon the qualities of steel wire (Einfluss der Walzdrahtvorgluehung, der Patentierungstemperatur und der Randentkohlung auf die Eigenschaften von Stahldraht). Drahtwelt, vol. 34, No. 22, 1941.

44. Reimann, E. : Hardening (Das Haerten). Publisher : G. B. Teubner, Berlin, 1942.

45. Reiser-Rapatz: The Hardening of Steel (Das Haerten des Stahles). Publisher Artur Felix, Leipzig, 1932.

46. Riebensahm, P. : Heat Treatment Shop News (Haertereitechnische Mitteilungen), vol. 1. Publisher : Union - Deutschland Verlagsgesellschaft, Berlin, 1942.

47. Schulz, E.H. and Puengel, W. : Bericht Werkstoffausschuss VDEh No. 100 (1927).

48. Schwier, F. : Influence of different drawing conditions upon the deformation efficiency and the ultimate strength in drawing steel wire (Einfluss verschiedener Ziehbedingungen auf den Formaenderungswirkungsgrad und die Festigkeitseigenschaften beim Ziehen von Stahldraht). Stahl und Eisen, No. 24, vol. 61, 1941.

49. Stanton, E. : Engineering, vol. 2, 1906, p. 33. Report in "Stahl und Eisen ", 1906, p. 1217.

50. Stanton, E. and Bairstow, L. : Engineering, vol. 2, 1908.

51. Stegwee, J.G. C. : Tests on the isothermal Hardening of Steel (Versuche ueber die isotherme Haertung von Stahl). Phillipps Technische Rundschau, September, 1941.

52. Stromberger, C. B. : A new endurance impact apparatus (Ein neues Dauerschlagwerk). Dissertation, Darmstadt 1930.

53. Thum, A. and Bergmann, G : Endurance Testing of Full Scale Form Elements and Part (Dauerpruefung von Formelementen und Bauteilen in natuerlicher Groesse). Z. VDI, vol. 81, 1937, pp. 1013-1018.

54. Timoshenko-Lessells : Strength of Materials (Festigkeitslehre). Berlin 1928.

55. Wiegand, H. : Nitriding in Engine Production (Nitrieren im Motorenbau). Haertereitechnische Mitteilungen, vol. 1, 1942. Fig. 27

56. Wiegand, H. and Scheinost, R. : The Endurance Limit of hard chromed Specimens (Die Dauerfestigkeit hartverchromter Proben). Z. VDI, vol. 83, 1939, p. 655.

\section{S A E バネ委員会の引用文献}

1. Almen, J. O., "Fatigue of Metals as Influenced by Design and Internal Stresses", American Society for Metals, Detroit, November, 1942.

2. Almen, J. O., "Shot Blasting to Increase Fatigue Resistance". S. A. E. Journal (Transactions), Volume 51, Number 7, July, 1943, 
3. Almen, J. O., "Improving Fatigue Strength of Machine Parts", Mechanical Engineering, August, 1943.

4. American Wheelabrator \& Equipment Compary, "Shot Peening", published by company, 1946

5. Balleisen, Maj. C. E., "Principles of Firearms", John Wiley \& Sons, Inc., 1945.

6. Battelle Memorial Institute, "Prevention of the Failure of Metals Under Repeated Stress", John Wiley \& Sons, Inc., 1941.

7. Clark, H. H., "Stranded Wire Helical Springs for Machine Guns", Product Engineering, July, 1946.

8. DeJuhasz, K. J., "Graphical Analysis of Surges in Mechanical Springs", Journal of the Franklin Institute, Volume 226, Numbers 1354 and 1355, October and November, 1938,

9. DeJuhasz, K. J., "Graphical Analysis of Free Vibrations of Helical Springs", Journal of the Franklin Institute, Volume 227, Number 1361, May, 1939.

10. Fuchs, H. O., "Forced Vibrations and Resonant Frequencies in Machinery", Product Engineering, July, August, and December, 1938.

11. Fuchs, H. O., and Mattson, R. L. " "Measurement of Residual Stresses in Torsion Bar Springs", Proceedings of the Society for Experimental Stress Analysis, Volume IV, Number 1, 1946.

12. Gustafson, J. R., "The Cleaning and Cadmium Plating of Spring Products", Muehlhausen Spring Corporation, 1942.

13. Hayes, Col. T. J., "Elements of Ordnance", John Wiley \& Sons, Inc., 1938.

14. Horger, O. J., "Effect of Surface Rolling on the Fatigue Strength of Steel", Journal of Applied Mechanics, Transactions of American Society of Mechanical Engineers, Volume 57, 1935.

15. Horger, O. J., "Mechanical and Metallurgical Advantages of Shot Peening", The Iron Age, March 29 and April 5, 1945.

16. McAdam, Jr., D. J., "Fatigue and Corrosion Failure of Spring Materials", Transactions of American Society of Mechanical Engineers, Volume 51, 1929.

17. Nadai, A., "Plasticity", McGraw - Hill Publishing Co., Inc., 1931.

18. Richards, D. G., "A Study of Certain Mechanically-Induced Residual Stresses", Proceedings of the Society for Experimental Stress Analysis III, Number 1, 1945.

19. S. A. E. War Engineering Board Spring Committiee, "Manual on Design and Application of Helical and Spiral Springs for Ordnance", 1943.

20. Sachs, G. and Epsey, G., "The Measurement of Residual Stress in Metal", The Iron Age, September 18 and 25, 1941.

21. Sachs, G. "The Flow and Rupture of Metals", Part III, Heat Treating and Forging, November 1941.

22. Tatnall, R. R., "Hydrogen Embrittlement of Spring Steels", Wire and Wire Products, October, 1943.

23. Wahl, A. M., "Mechanical Springs”, Pentor Publishing Co., 1944.

24. Zimmerli, F. P., "Permissible Stress Range for Small Helical Springs", Engineering Research Bulletin No. 26, University of Michigan, July, 1943.

25. Zimmerli, F.P., "Shot Blasting and Its Effects on Fatigue Life", in book: "Surface Treatment of Metals", American Society for Metals, 1941.

26. Zimmerli, F. P., "Carbon and Alloy Steel Materials for Cold-Formed Springs", Product Engineering, October, 1946. 